\title{
How Argentina became a super-exporter of agricultural and food products during the First Globalisation
} (1880-1929)

\author{
Vicente Pinilla ${ }^{1}$ (D) Agustina Rayes ${ }^{2}$ \\ Received: 11 April 2018 / Accepted: 20 September 2018 \\ (c) Springer-Verlag GmbH Germany, part of Springer Nature 2018
}

\begin{abstract}
The objective of this paper is to explain, from a cliometric perspective, the determinants of the growth of Argentina's exports between 1880 and 1929. To do this, we have constructed a gravity model with the principal products exported each year by Argentina to its most important trading partners. In this way, we believe that this study constitutes a relevant and original contribution to the analysis of economic growth from a historical perspective and specifically in explaining the factors determining the export success of the settler countries during the first wave of globalisation. Our results show that Argentina's export-led growth must be explained from both the supply and demand sides. We also find that the reduction in trade costs and trade liberalisation, especially the latter, boosted exports. We also support the idea that Argentina had a successful agro-export sector because it offered a diverse basket of products to the different European and American countries that consumed them. To sum up, we can conclude that Argentina took advantage of a multilateral and open economic system. Within this context, the country generally found a demand for its supply, which constitutes the key to explaining the magnitude and speed of Argentina's export growth.
\end{abstract}

Keywords Settler economies · Latin American economic history · First Globalisation · International trade

JEL Classification F14 $\cdot$ N56 $\cdot$ N76 $\cdot$ Q17

Electronic supplementary material The online version of this article (https://doi.org/10.1007/s1169 8-018-0178-0) contains supplementary material, which is available to authorized users.

Vicente Pinilla

vpinilla@unizar.es

1 Universidad de Zaragoza and Instituto Agroalimentario de Aragon (IA2), Zaragoza, Spain

2 Universidad Nacional de San Martín and Consejo Nacional de Investigaciones Científicas yTécnicas, Buenos Aires, Argentina 


\section{Introduction}

The long nineteenth century constitutes a crucial period in economic history as it represents the advent of a new era during which modern industry was not only consolidated in its British birthplace but was also extended to other countries such as those in north-west Europe, the USA and Japan.

However, the populations of some extra-European countries were also able to earn high incomes but with low levels of industrialisation. These countries had been recently colonised by Europe (Canada, Argentina, Uruguay, Australia and New Zealand), and their economic growth was based on the rapid expansion of their exports of primary products and on the linkage effects of these exports with other economic activities (Smithies 1966; Duncan 1984; Pomfret 1981; Fogarty 1985; Alvarez et al. 2007; Míguez and Rayes 2014). Almost all of these countries were ranked among the world's top ten economies in terms of per capita income in 1913 (Uruguay was the 14th) (Maddison project 2013). The export-led growth models of these countries were based on the strong integration and complementarity of their economies with European countries that were at a more advanced stage in their industrialisation process, especially the UK. These settler countries exported primary products to the most developed European nations, drawing from their abundant natural resources (particularly land). In return, they imported scarce factors of production (labour and capital) and manufactured goods (Schedvin 1990; Denoon 1983).

Other countries, mainly in tropical areas, including the majority of Latin American countries, also tried to stimulate growth through the expansion of their exports. However, the results were more modest than those of the settler countries, due to the much slower pace of their export growth and the weak linkages of their exports with the rest of the economy, two essential elements of the model (Cortés Conde and Hunt 1985). Bulmer-Thomas (1994) has already shown that cases with relatively diversified baskets, such as Peru or Mexico, had a higher concentration than Argentina in terms of the value exported to their main destinations. Recently, in a comparison of the export performance of Argentina, Bolivia, Brazil, Chile, Colombia, Mexico and Peru, Kuntz-Ficker (2017: 316) characterised the former as an outlier since, with a 4\% average growth rate for exports between 1870 and 1929, Argentina reached a maximum level of 865 million dollars, while Mexico, with a remarkable average export growth rate of $6 \%$ per year, reached a top export value of 227 million dollars (both at constant 1913 prices).

The increasing international integration that took place from the first half of the nineteenth century, known as the First Globalisation, therefore constitutes the framework within which these export-led growth experiences were developed. It is well known that until the First World War, trade grew at a fast pace (3.9\% between 1817 and 1865 and $3.1 \%$ between 1865 and 1913) and faster than production (Federico and Tena-Junguito 2016). This growth in trade was driven by a series of factors such as the industrialisation process itself which shifted the demand and supply curves to the right, due to the technical changes, the fall in transport costs and the trade liberalisation process experienced by the Atlantic economies (Jacks 2006; Jacks et al. 2011). The trade of agricultural and food products also increased strongly until the 


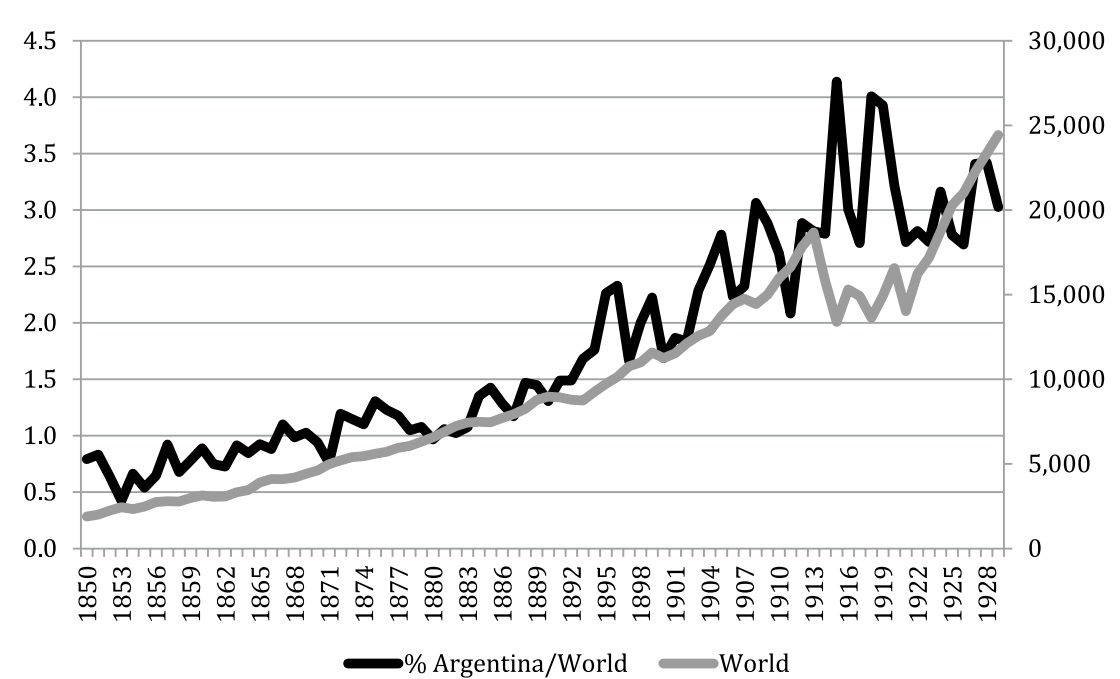

Fig. 1 Ratio of Argentine exports over world exports (\% at current prices) and world exports (millions 1913 \$). Source Federico and Tena-Junguito (2016)

outbreak of the First World War due to the same causes (Aparicio et al. 2009, 2018; Pinilla and Ayuda 2010).

Within this context, some countries that specialised in the production and export of primary products, with a high demand from north-west Europe due both to the fast population growth arising from the demographic transition and to the increase in the per capita income of its population, were able to achieve rapid economic growth. This was the case of Argentina during these years.

According to the recent estimates of world trade published by Federico and TenaJunguito (2016), Argentine exports, which represented around $0.8 \%$ of world trade during the early 1850 s, reached levels of almost $4 \%$ in the 1920 s (Fig. 1). According to the data provided by these authors, of the countries that represented more than $1 \%$ of world trade between 1875 and 1929, only Canada and Japan increased their share at a faster rate than Argentina. Cardenas et al. (2003) show that in 1860 Argentine exports accounted for only $4.5 \%$ of the total value exported by Latin America. However, this percentage increased to $29.3 \%$ in 1911-1913 and before the Great Depression it reached $32.7 \%$. These trends coincide with the League of Nations (1942) and Bulmer-Thomas (1994) data. Although there are no estimates with respect to the weight that Argentine exports had of the world trade of primary products, Pinilla and Aparicio (2015) have calculated that, between 1900 and 1938, the whole of South America represented between 10 and 15\%. Argentina's participation could be estimated as being around half of the total for the region. Therefore, during the socalled First Globalisation, Argentine exports grew extremely fast, as did its GDP, and the country became a paradigmatic case of export-led growth (both, exports and GDP, had growth rates 5.2\%, according to Bértola and Ocampo (2013: 125). In fact, exports represented about a fifth of its GDP between 1900 and 1929 (Winograd and Véganzonès (1997: 1997). Therefore, Argentina is a highly important case study due 
to its rapid export growth and is a good reflection of what happened in other settler economies.

For many years, the export-led growth model of settler countries has attracted the interest of researchers. It could be said that the study of this model has given rise to one of the theoretical contributions made by economic history to economics: the staple theory (Watkins 1963). Furthermore, considerable empirical research in economic history has focused on these growth experiences, both from a comparative perspective and through case studies. This has generated a rich body of the literature that provides an insight into how the colonisation process was developed, how the new lands were exploited (after being taken from the native populations), how the production destined for export expanded, how the capital or labour from Europe arrived and how all of these factors affected economic development (Lloyd et al. 2013; Findlay and Lundahl 2017).

However, there are very few studies that use a cliometric perspective in order to identify the determinants of such an accelerated growth in exports, which is a necessary condition for the export-led model to work. Obviously, the above-mentioned literature has quantified and studied the volumes of the exported goods, their destinations, the domestic conditions for expanding production, the contribution of factors of production from abroad or the external demand conditions. Nevertheless, from our point of view, a relevant contribution may be made from a cliometric perspective by integrating different relevant variables into a model so as to clarify and specify the principal causes of the export growth.

Within this context, the objective of this article is to provide a cliometric contribution to this field of study, constructing a gravity model to explain the determinants of the growth of Argentina's exports between 1880 and 1929. It should be pointed out that this study does not stop in 1913, as is generally the case in historiography. This is because although the international rules of trade started changing after the Great War, the export-led growth model in Argentina continued until the Great Depression, when the exports were significantly affected, both in volume and in value (O’Connell 1984; Bulmer-Thomas 1994; Gerchunoff and Llach 2007).

To do this, we have constructed a gravity model with the principal products exported each year by Argentina to its most important trading partners. Over the last three decades, these models have become the most commonly used methodology to analyse the determinants of international trade. We have applied the model to data that have been drawn from a meticulous review of the Argentine foreign trade statistics (see Appendix 1 in the Supplementary material). In contrast with the vast majority of the quantitative analyses of this subject, we have studied the annual path of the principal export products, that is, the destinations of each individual product. The main differences with the official statistics are that we have corrected the official values, when they did not represent the market prices, and we have assigned the exports "for orders", which affected mostly the forest and agricultural products, sent to European possessions without recording their final destination (for more detail, see Rayes 2013b).

In this way, we believe that we have made a relevant and original contribution to the analysis of economic growth from a historical perspective and specifically in 
order to explain the factors determining the export success of certain countries during the First Wave of Globalisation.

Our results reveal that both the expansion of external demand and the development of the Argentine economy were key factors for the extremely rapid growth of exports. The fall in transport costs and the reductions in tariffs were also important contributing factors.

These overall results are better understood when analysed by the types of product. This also constitutes an original contribution since the literature has generally not differentiated between different export goods. In this case, significant peculiarities may be observed. The development of the Argentine economy constituted an obstacle for the growth of its exports of livestock products (unprocessed), as agriculture competed for the land on which this activity was developed. Furthermore, the emergence of a meat-processing industry gave rise to a preference for the export of frozen and chilled meats as opposed to live animals. The opposite was the case for raw agricultural and processed agrifood products that experienced an improvement in exports as a result of the country's economic growth.

This article has been divided into five parts. It begins by analysing the trends of Argentina's export growth. It then goes on to present the theoretical framework and econometric model. The third section offers the results for Argentine exports as a whole. Subsequently, the results of the econometric models for different types of products are analysed and the conclusions are drawn. Finally, the paper has an appendix, which explains the sources on which the data are based.

\section{The trends of Argentine export growth}

It is well known that during the First Globalisation Argentine exports experienced long-term growth. But the details of this growth, in terms of both value and volume, have been studied with less precision. Furthermore, in order to better understand a process spanning almost six decades, it is not enough to have data for specific years. Using more reliable statistics than the official data, this paper examines how and when growth took place. The following chart summarises Argentine exports in current and constant values (calculated with the prices of 1913) (Fig. 2).

As we can see, Argentina's integration into international markets was successful after the 1870s. But, according to Cortés Conde and Hunt (1985: 342), it was not until the last decade of the nineteenth century that exports contributed to paying for debt services and to financing imports, which was necessary not only to transform the productive structure but also to cover the consumption needs of the domestic market. But, how did this come about?

The chart above indicates that both volume and value increased together until the First World War. Nonetheless, this rise was stronger in volume than in value, even when commodity prices fell abruptly between the mid-1880s and mid-1890s. The literature has attributed this growth to several causes.

Before looking at internal causes, it is important to point out that almost all the literature has focused on demand to explain the success of Argentina as an agricultural exporter. The country benefited from the existence of a multilateral system, 


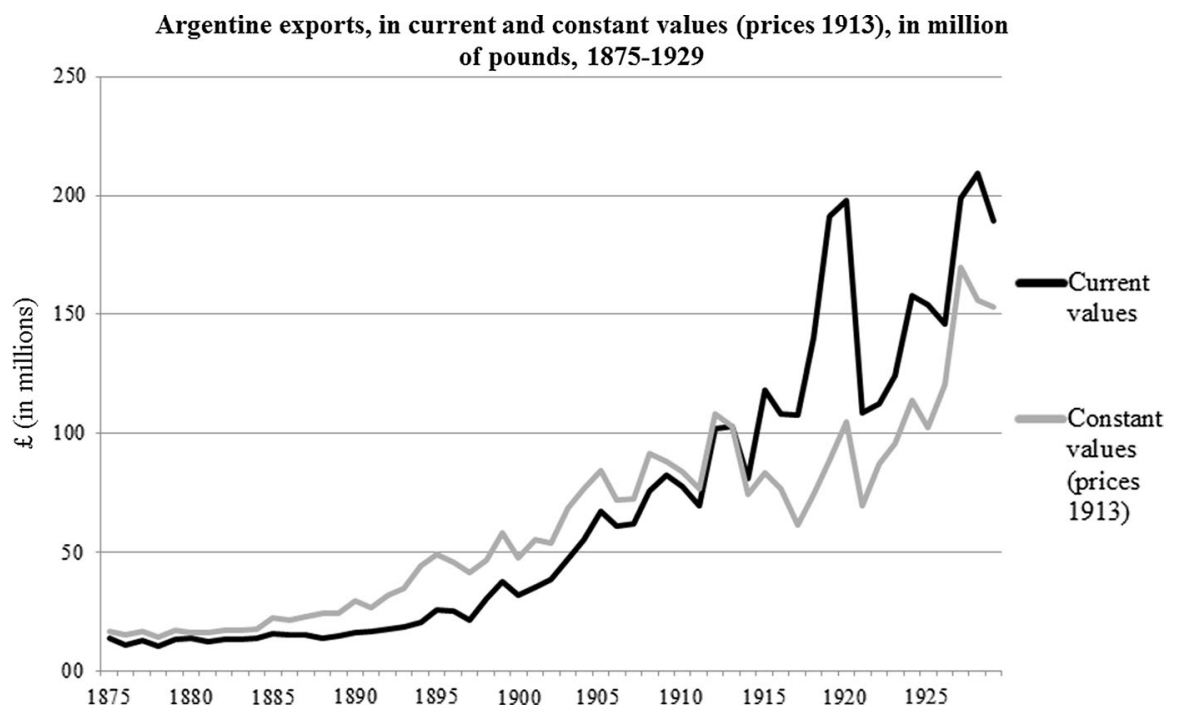

Fig. 2 Argentine exports, in current and constant values (1913 prices), in millions of pounds, 18751929. Source own elaboration according to official Argentine statistics (1875-1929) and Cortés Conde et al. (1965)

liberal trade policies and the gold standard (Cortés Conde 1974; Gerchunoff and Llach 2007; Míguez 2008; Rocchi 2011; Francis 2017). Furthermore, it was able to cover the European, and especially the British need for commodities and raw materials (Ferrer 2008: 143-146, 195-211; Platt 1972: 251-273).

In general, it has been claimed that the export growth was partially due to falling costs in transatlantic and internal transportation-with respect to the latter, railroad expansion had a relevant role (Bértola and Ocampo 2013: 103). Otherwise, low unit value products, such as grains, would not have been able to access the distant European markets and compete with North American and Eastern European harvests. The transportation revolution benefited those countries with "heavy" baskets, such as Argentina (Gerchunoff and Llach 2008). So, a window of opportunity was opened for agricultural and food products (Cortés Conde et al. 1965: 41-43; Bulmer-Thomas 1994: 81-98; Rayes 2014a), especially those produced in areas near to ports or areas that received investments in railroads because, as Fajgelbaum and Redding (2014) proved, the reduction in transport costs did not have the same effects across the whole country.

During the last quarter of the nineteenth century, most of the exports were derived from cattle rearing. In fact, only two of the top ten exports were agricultural products. Continuing the trend of the previous few decades, the exports of raw wool and the different types of hides dominated the scene. This was due in part to the production structure of the Pampas, characterised by a relative abundance of land and a relative scarcity of capital and labour (Cortés Conde 1974: 161). This started to change in the final decades of the nineteenth century, with the arrival of immigrants and foreign capital. Subsequently, the supply of labour available for farming and 
Table 1 Population and production in Argentina, 1880, 1913 and 1929. Source Own elaboration based on Ferreres (2010)

\begin{tabular}{lrrr}
\hline Indicators & \multicolumn{1}{c}{1880} & \multicolumn{1}{c}{1913} & \multicolumn{1}{c}{1929} \\
\hline Population & $2,559,839$ & $7,614,761$ & $11,616,970$ \\
Length of railway lines (in km) & 2516 & 32,494 & 37,551 \\
Cultivated area of wheat (in ha) & 73,100 & $6,918,000$ & $9,219,000$ \\
Cultivated area of corn (in ha) & 13,040 & $3,830,000$ & $4,788,000$ \\
Cultivated area of linseed (in ha) & 34 & $1,900,000$ & $2,809,900$ \\
Existence of bovine cattle (in units) & $19,854,000$ & $25,867,000$ & $32,212,000$ \\
Existence of ovine cattle (in units) & $67,701,000$ & $43,225,000$ & $44,413,000$ \\
\hline
\end{tabular}

For the year 1880, the data for cultivated areas were taken in 1872 . The existence of cattle was considered in 1881,1914 and 1930

harvesting the fields increased. Capital was invested, for example, in public works, such as the construction and the improvement in ports, and the laying of rail lines (Ford 1966: 146; Vázquez Presedo 1979: 143-175). Table 1 presents data on population and production that we consider relevant to show a part of the expansion of the Argentine economy.

Additionally, the Argentine state extended its control. Through conflicts with native inhabitants, it redefined international borders with neighbouring countries, and as a result new lands were integrated into the export sector (Di Tella and Zymelman 1967: 38-76; Míguez 2008: 241-260; Vitelli 2012: 131-132). In fact, this case has been used to illustrate the competitive advantage theory of commerce. The exports based on land-intensive products coincided with the low opportunity cost of this factor of production (Díaz Alejandro 2002: 24-32).

Land was considered as one of the main factors explaining export growth. In fact, some literature argues that in the pre-war years, growth slowed down because the border could not be extended any further. However, recent research has found that the growth was not based solely on the aggregation of land but on the changes of land uses and the human and technical capital invested in it (Cortés Conde 2003: 361).

Once Argentina had successfully penetrated international markets, agriculture became an important export sector. In fact, although the number of livestock items was greater between the beginning of the twentieth century and the Great Depression, three agricultural goods (wheat, corn and linseed) accounted for almost half of the total export value from the beginning of the twentieth century. But we must not forget the role of frozen and chilled beef, which strengthened their position in the export basket after the decline in live cattle shipments due to animal health issues at the end of the nineteenth century (Rayes 2015).

As shown in Fig. 2, the First World War constituted a turning point. The drop in the volume of exports clearly demonstrates the Argentine dependency on foreign trade and the rules that governed it. The conflict did not affect growth in terms of prices. On the contrary, Argentina benefited from the adversaries' need for certain raw materials (such as wool and salted cattle hides) and food (such as frozen beef, 
wheat, corn and canned meat). However, the war paralysed export growth in terms of volume due to the shortage of ships and the consequent increase in transport costs (Fodor and O'Connell 1973; Gravil 1985; Albert 1988; Rayes 2014b: 39-40). Rather than a single trend, the post-war years were characterised by peaks and troughs. In fact, before the Great Depression, Argentine exports experienced a sharp contraction between 1920 and 1921. But, during the second half of the 1920s, the exports grew, partially due to the retraction of competitors such as the USA or the countries of the Balkans basin (Gerchunoff and Aguirre 2006).

According to our corrected data, the average annual amount increased more than sixfold in the period 1900-1929 in comparison with the period 1875-1899. This growth is partially explained by the diversification of the export basket. To illustrate this, we have drawn up a table constructed with new empirical evidence. ${ }^{1}$

During the early decades of the twentieth century, processed agrifood exports achieved greater prominence. In Table 2, the statistical data show the diversification of the meat produced for cold storage, the growth of wheat flour and quebracho extract exports. Together these products constituted a sizeable share as they represented more than a fifth of the total export value from the beginning of the twentieth century. This study highlights their participation because the previous literature has broadly described Argentina as an exporter of only primary goods, ignoring the role that individual items had in backward and forward linkages.

Another interesting finding from the data corresponding to the period 1900-1929 is the assortment of the traded goods that were purchased for different uses. For example, meat, wheat and wheat flour were served as food; corn, linseed and oats were used for fodder; linseed hides, wool and quebracho extract were sold as supplies for different segments of the textile industry (clothing, saddlery, leather dyeing, carpet manufacturing, among others). We believe that this situation probably prevented overall exports from suffering due to crises occurring in any one particular sector.

We have already emphasised the clear upward trend both in the value and in the volume of the traditional exports, such as raw wool, dried cattle hides and salted cattle hides, and in the value of raw sheep skins after the 1900s. This finding indicates that the previous literature has underestimated the role of these kinds of exports. Even though a few researchers (Cortés Conde et al. 1965; Bulmer-Thomas 1994; Díaz Alejandro 2002) have alluded to the coexistence of new exported goods with traditional ones, it has not been studied systematically. In contrast, the historiography has placed special emphasis on the goods that experienced export growth after the late nineteenth century. Of course, their performance was spectacular. During the early decades of the twentieth century, wheat, corn and linseed multiplied their volume by several times and this affected their contribution in terms of value. The same was the case for frozen beef and mutton, but these grew to a lesser extent than in the previous period.

\footnotetext{
1 We have followed the subdivision considered by Kuntz-Ficker and Rayes (2017: 43) as an alternative to dividing by decades or the Maddison phases.
} 


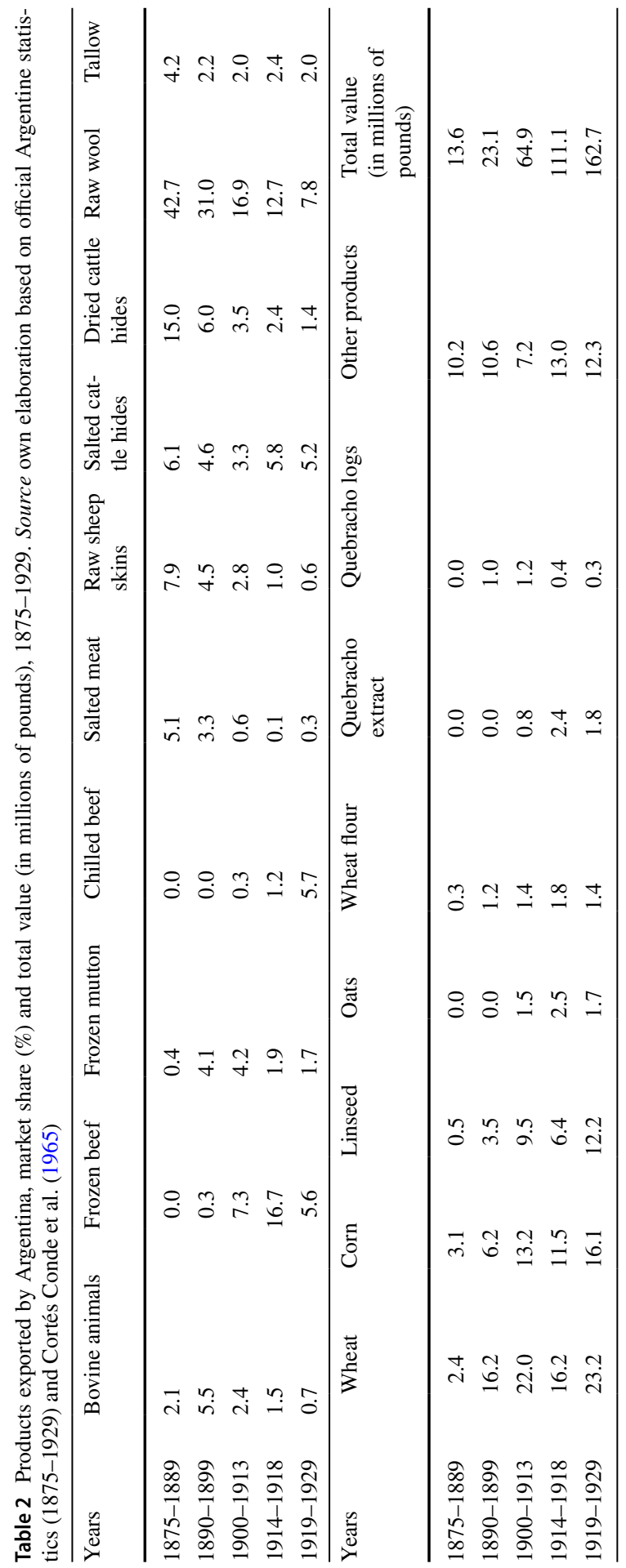




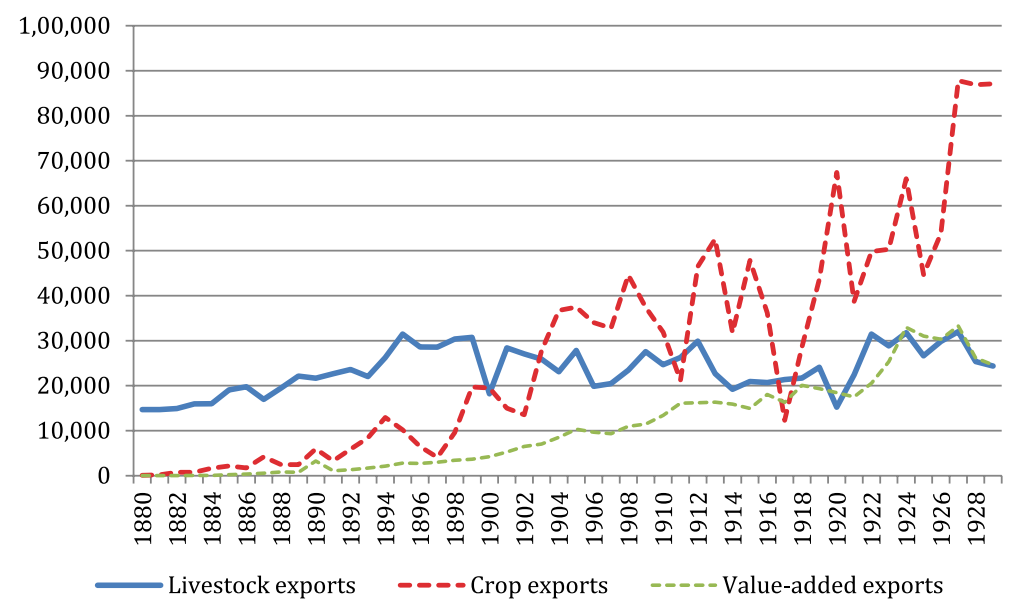

Fig. 3 Breakdown of Argentine exports at constant prices of 1913 (thousands of pounds). Source own elaboration based on official Argentine statistics (1875-1929) and Rayes (2015)

So, this study does not deny the overwhelming export success of the new products; however, it warns that focusing exclusively on these products leads to wrong conclusions about the period. In fact, the results reveal that, beyond the fluctuations already indicated, the survival of the old exports contributed to averting major crises until the Great Depression. In other words, under normal circumstances, problems could arise in certain sectors or in certain countries, but not all at once. A historical example can help to explain this idea. In 1900, Argentine wool exports fell due to the crisis suffered by their main buyers. The volume sent to France declined to one-third, while exports to Germany and Belgium halved. Since its peak, this was the first year that wool was not the number-one export product, representing $18.1 \%$ of total exported value, half of its share of the previous year. Nonetheless, the total amount of exports was higher than the average for the previous five-year period, when there was already a growth trend. This was because the trade partners, including those who had suffered the wool crisis, bought other products from Argentina.

To analyse export growth, we have separated the products into three groups: (1) traditional livestock exports, which include wool, salted and dried cattle hides, raw sheep skins, bovines, jerked meat and tallow; (2) crop exports that consider wheat, corn and linseed and (3) processed agrifood exports, which are composed of chilled and frozen beef, frozen mutton, wheat flour, quebracho logs and quebracho extract. As we can see, although the first group also grew, if we ignore the fluctuations and focus on a long-term perspective, the second and the third groups grew more and at a faster pace (Fig. 3).

Finally, to complete our research on Argentina's exports, it is fundamental to study their geographical distribution. The analysis of Argentine export performance has mostly focused on the composition of trade rather than its geographical distribution, with few exceptions such as Vázquez Presedo (1971) or Tena-Junguito and Willebald (2013). Indeed, the literature has not always combined both aspects in its analysis. This is probably due to the idea, which can be seen in research conducted 
Table 3 Geographical distribution of Argentine exports, market share (\%) and total value (in millions of pounds), 1875-1929. Source Own elaboration based on official Argentine statistics (1875-1929) and Cortés Conde et al. (1965)

\begin{tabular}{|c|c|c|c|c|c|c|c|}
\hline Years & Germany & Belgium & Brazil & Chile & Spain & USA & France \\
\hline $1875-1889$ & 7.2 & 22.1 & 3.5 & 2.6 & 2.2 & 7.5 & 26.5 \\
\hline 1890-1899 & 13.7 & 12.4 & 8.9 & 1.7 & 1.5 & 5.2 & 20.8 \\
\hline 1900-1913 & 16.9 & 10.7 & 4.4 & 0.5 & 0.6 & 4.9 & 11.9 \\
\hline 1914-1918 & 1.9 & 1.3 & 5.2 & 0.6 & 1.9 & 20.8 & 11.7 \\
\hline 1919-1929 & 10.1 & 9.6 & 5.0 & 0.5 & 1.2 & 11.7 & 8.2 \\
\hline Years & Italy & $\begin{array}{l}\text { The Nether- } \\
\text { lands }\end{array}$ & UK & Uruguay & $\begin{array}{l}\text { Other desti- } \\
\text { nations }\end{array}$ & $\begin{array}{l}\text { Total } \\
\text { (in m } \\
\text { poun }\end{array}$ & ns of \\
\hline 1875-1889 & 3.5 & 0.1 & 12.2 & 3.5 & 9.1 & 13.6 & \\
\hline 1890-1899 & 3.2 & 1.0 & 22.1 & 3.5 & 6.0 & 23.1 & \\
\hline 1900-1913 & 2.6 & 4.3 & 34.1 & 1.4 & 7.7 & 64.9 & \\
\hline 1914-1918 & 6.0 & 2.7 & 37.6 & 1.6 & 8.7 & 111.1 & \\
\hline 1919-1929 & 5.5 & 7.1 & 30.0 & 0.8 & 10.3 & 162.7 & \\
\hline
\end{tabular}

from different theoretical perspectives, that the main trade partners of Argentina were European economies, particularly Great Britain.

However, it is not only necessary to identify the trade partners but also to determine how they participated in total trade. The existing literature recognises the critical role played by the concentration of markets. In the Argentine case, one of the main obstacles to studying this aspect is the lack of reliable long-term evidence. As already pointed out, the historiography has worked with official statistics that have not been reviewed. One of the most serious attempts to obtain a reliable series, performed by Cortés Conde et al. (1965), did not consider export destinations. In contrast, as previously explained, the data on which this paper is based have been reconstructed. So, as given in Table 3, this study presents the share of each of the principal destinations, which accounted for more than $90 \%$ of the total value of exports.

In the period 1875-1899, the main trade partner was France, followed by Belgium. These two countries had been the major destinations since Argentina began its rise in the international market from the second half of the nineteenth century. Together, they accounted for a little over $40 \%$ of total exports. This changed in the early decades of the twentieth century (1900-1929), when their share fell to just below $20 \%$ of total exports. However, a distinction should be made between relative and absolute performance. During the early decades of the twentieth century, France and Belgium almost trebled their annual amount. This calls us to reflect on the other partners.

The UK ranked third until the 1890s, after which it became Argentina's main destination. While accounting for a similar share to France in the last decade of the nineteenth century, from the beginning of the twentieth century, the British market was greater than any other destination in the period studied. In 
fact, it concentrated a third of the total value of Argentina's exports, a trend that increased slightly during critical years such as the First World War. But it is important to note that the UK made a difference from the early years of the twentieth century and not before. Several studies that highlight the "special relations" between Argentina and UK have not explained the changes over the whole period. ${ }^{2}$ Moreover, the study of this connection has overshadowed the analysis of other relationships. But what about the remaining two-thirds of total exports?

It was not only the UK that improved its position as an export destination in the early decades of the twentieth century with respect to its development in the final years of the previous century. Germany became the second destination. Although the percentage was almost the same, its monetary contribution grew by seven times. Its growth as a trade partner partially justifies Argentina's neutrality during the Great War (Weinmann 1994; Rayes 2014b).

The USA progressed both in relative and in absolute terms. It increased its purchase value by more than nine times and became particularly prominent during war and post-war years. Its performance should be highlighted because this trade partner has traditionally been perceived as a competitor (Peterson 1964; Rocchi 2011).

Another successful case was the Netherlands, which began to be listed in official statistics from the end of the 1880s although it accounted for no more than $1 \%$. Its share increased sharply during the twentieth century, particularly in the post-war period. Other minor partners were located both in Europe and in South America. Spain and Italy were destinations of some exports, but the latter was more important. This market grew markedly after the First World War. In contrast, the Spanish market hardly absorbed $2 \%$ of the total value.

In Latin America, only Argentina's neighbours played a relatively significant role in the geographical distribution of its exports. The shares of Chile and Uruguay which were established during colonial times progressively lost importance. On the contrary, Brazil significantly increased its participation as a trade partner, not only with other countries of the region but also with European countries. According to our data, intra-regional trade-which included, of course, more countries than the three presented in Table 3-fluctuated, depending on the years considered. It represented no less than $10 \%$ and peaked at $20 \%$ of total exported value. These results seem to be consistent with other studies that focus on South American intra-regional trade during the First Globalisation to compensate for the attention being exclusively aimed at the economic relations with Europe and the USA (for example, Carreras-Marín et al. 2013).

In contrast with the composition of trade, the geographical distribution became more concentrated between 1900 and 1929 since the largest partner, the UK, represented a third of the total value in comparison with France, which accounted for a quarter during the period 1875-1899. Nevertheless, the second and the third largest partners had lower shares in the early decades of the twentieth century than before.

Going beyond the different shares, almost all of the partners improved in absolute terms. This obviously benefited Argentina's performance. The same was the case

\footnotetext{
${ }^{2}$ For a critical vision, see Míguez and Rayes (2014).
} 
for most of the products, almost all of which improved in absolute terms. However, how could this be so? This study will explore the determinants of Argentina's export growth by applying an econometric model. But before we do this, we must explain the empirical evidence, the sources and the methodologies that we have used.

\section{Theoretical framework, econometric model and data}

In order to explain the growth of Argentine exports within the context of the First Globalisation, we should take into account the changes occurring with respect to Argentina's supply of exportable products, the international demand for these products and the commodity market integration. In other words, we should consider which Argentine exports grew as a consequence of the rightward shift of the country's export supply curve, the demand curve of its trading partners and those of the factors that stimulated the First Globalisation. These factors include primarily the reduction in transaction costs, particularly transport (inland and transatlantic) and the liberalisation of trade which, since the mid-nineteenth century, reduced the previously high tariffs that prevailed. In general, in the different studies that analyse the evolution of Argentina's export sector, it is assumed that all of these variables could have been relevant, although there is no empirical study that measures the effect of each of them and their significance. On the whole, greater emphasis is placed on the existence of a strong external demand, mainly from the UK, to which the Argentine economy responded by placing the corresponding products on the market.

Our objective is, therefore, to propose a model that is able to verify the importance of each of the aforementioned variables when explaining the determinants of Argentina's export growth. Furthermore, as explained in the previous section, breaking away from the mainstream explanation for this success, we will focus our analysis in two directions: first we will consider that the export success was based on the capacity of the country to vary its export basket, from livestock products with a very low level of processing to agricultural products and finally agro-industrial products. All of this required the Argentine economy to play an active role which means that we must focus on supply more than is usually the case. Second, we seek to highlight that Argentina's export destinations were less concentrated on the British market than is commonly believed and included a much wider number of countries. Therefore, it is important that we do not focus solely on this market but analyse all of the others that were relevant for Argentine exports.

In order to achieve these objectives, we believe that a gravity model with panel data is able to provide more robust results. This methodology has been widely employed to investigate the principal determinants of trade. Its main advantages are its explanatory power with regard to bilateral trade flows and the stability of the results obtained. As we are working with bilateral flows, we are able to take into account the characteristics of the principal trading partners of Argentina with annual data and over a very broad period of time between 1880 and 1929. Furthermore, and given that different types of products were successively incorporated into the export basket, we believe that in addition to considering a general 
model for all of the country's exports it is important to also consider a model for each of the three groups of goods into which we can divide the country's exports: livestock products, agricultural products and processed agro-industrial products. In this way, we will be able to determine whether or not the determinants of the growth in trade were the same for the three types of products.

We will now describe the specification of the gravity equation used. The empirical approach is based on Feenstra et al. (1998), Bergstrand (1985, 1989) and Anderson and van Wincoop (2003). The success of this methodological approach in explaining international trade patterns has led to the formal development of its theoretical foundations. The empirical validations of the gravity equation (Helpman (1987), Hummels and Levinsohn (1995), and Evenett and Keller (2002)) conclude that the equation can be derived from different theoretical models. This is an eclectic vision of the determinants of trade which includes, complementarily, the Hecksher-Ohlin models with specialisation (Anderson 1979; Deardorff 1984; Anderson and van Wincoop 2003) and the models of the New International Trade Theory with increasing returns and monopolistic competition (Helpman and Krugman 1985). The functional specification of the models used here largely follows the work of Anderson, Bergstrand and Anderson, and van Wincoop, and the "multilateral resistance" phenomenon is also taken into account.

We have used a standard constant elasticity of substitution model:

$$
X_{i j t}=\beta_{1} Y_{i t}^{\beta_{2}} Y_{j t}^{\beta_{3}} F R_{j t}^{\beta_{4}} T_{j t}^{\beta_{5}} .
$$

Applying logarithms to model (1), this becomes:

$$
\ln X_{i j t}=\beta_{1}^{*}+\beta_{2} \ln Y_{i t}+\beta_{3} \ln Y_{j t}+\beta_{4} \ln F R_{j t}+\beta_{5} \ln T_{j t}+\delta_{j}+\epsilon_{t}
$$

where $X_{i j t}$ represents export flows, by volume, from Argentina $(i)$ to country $j$ in year $t ; Y_{i t}, Y_{j t}$ are the real gross domestic products (GDP) of both Argentina (the exporting country) and the importing country, in year $t$; $\mathrm{FR}_{j t}$ is the ocean freight cost between Buenos Aires and the capitals of the countries of the destinations; and $\mathrm{T}_{j t}$ is the degree of tariff protection of the importing countries.

$\beta_{1}^{*}=\ln \beta$ and the additive error term, $\varepsilon_{t}$, is assumed to be identically and independently distributed.

The base of the gravity equation is initially represented by $X_{i j}$, which denotes the volume of the trade flow between a pair of countries, in our case exports from Argentina to its trade partners. We have constructed this series based on Argentina's foreign trade statistics (see Appendix 1 in the Supplementary material). For the period 1880-1929, a total of 550 observations have been made in all of the models except in the model for agricultural products in which there are 400.

The model includes the 16 most important Argentine export products during the period. ${ }^{3}$ These products represented between 85 and $90 \%$ of the value of Argentine exports. The model includes the eleven principal trade partners of Argentina for the

\footnotetext{
3 The products included in the model are: wool, salted and dried cattle hides, raw sheep skins, bovines, jerked meat, tallow, wheat, corn, linseed, chilled and frozen beef, frozen mutton, wheat flour, quebracho logs and quebracho extract.
} 
products with which we are working. ${ }^{4}$ These eleven countries represented between 85 and $97 \%$ of the value of the exports of these products from Argentina during the period under study. Therefore, we are satisfied with our database as, taking the products and countries included into account, its coverage varies between 72 and $87 \%$. As a result, the conclusions obtained from our model are sufficiently representative of Argentine exports as a whole.

In Eq. (2), $Y_{i}$ represents the size of the Argentine market, estimated in terms of GDP. $Y_{j}$ represents the size of the trade partners' markets, also approximated by their GDP (Maddison project 2013). The separate interpretation of these variables enables us to observe Argentina's capacity to offer (export) products depending on its size measured by GDP, while potential foreign demand for the products will depend on the size of the importing country's market (GDP). This model assumes that bilateral trade flows depend positively on the economic size of countries and negatively on the trade costs between them. In gravity models, the distance between two countries is usually used to approximate the transport costs between them, which are very difficult to measure for each pair of countries. In our case, we have included the variable $\mathrm{FR}_{i j t}$ which is an estimate of the evolution of the real transport costs between Argentina and its trade partners. To do this, we have drawn the annual transport costs series per tonne/mile of wheat between the port of Buenos Aires and Liverpool from Federico and Tena-Junguito (2016). We have multiplied this cost by the distance between Argentina and its different trade partners. ${ }^{5}$ This implies the assumption that transport costs per tonne/mile were similar for all products and destinations.

In order to observe the effect of the variation in the level of tariff protection of each partner, we have introduced the variable $T_{j t}$. As there are no series available with respect to how the tariffs of Argentina's trade partners varied for the different goods that it exported, we have used the estimate proposed by Clemens and Williamson (2004) for the degree of tariff protection after 1870 for a large number of countries. For those countries for which these authors do not provide data, we have used the estimates of Rubio (2011) and have estimated the remaining gaps. We realise that the tariff protection structure of a country is not necessarily representative of the products exported by Argentina, of which non-agricultural manufactured goods formed an insignificant part. Therefore, we assume the imperfection of this variable to examine the trade liberalisation of the products exported by Argentina.

We have also included year fixed effects in order to be consistent with the standard in the field. We have added a dummy variable for each trade partner so as to take the multilateral trade resistance into account. Anderson and van Wincoop (2003) observed a bias generated by omitting relevant variables such as the terms measuring the so-called multilateral resistance, which assume that trade decisions are made by contemplating relative and not absolute prices. Similarly, when working with

\footnotetext{
4 The trade partners of Argentina included in the model are: Germany, Belgium, Brazil, Chile, Spain, United States, France, Italy, The Netherlands, United Kingdom and Uruguay.

5 Alternatively, instead of the cost of transport we have used distance to approximate transport costs (CEPII). Logically, in this case, this variable does not change from year to year. The results obtained are very similar to those produced from our estimate of the real transport cost. They are available on request.
} 
Table 4 Results of the gravity equation for Argentine exports, 1880-1929

\begin{tabular}{lll}
\hline Variables & $(1)$ & $(2)$ \\
\hline 1_GDPi & $0.523 * * *$ & $1.562^{* * *}$ \\
& $(0.198)$ & $(0.501)$ \\
1_GDPj & $1.002^{* * * *}$ & $1.633^{* * *}$ \\
& $(0.192)$ & $(0.422)$ \\
1_Freight & -0.070 & $-0.564 * * *$ \\
& $(0.098)$ & $(0.084)$ \\
1_Tariff & $0.190 * *$ & $-0.319 * * *$ \\
& $(0.079)$ & $(0.094)$ \\
Year fixed effects & Yes & Yes \\
Time-invariant importer fixed effects & Yes & No \\
Importer decade fixed effects & No & Yes \\
Constant & -3.305 & $-20.54 * *$ \\
& $(2.015)$ & $(9.225)$ \\
Observations & 550 & 550 \\
$R$ squared & 0.879 & 0.952 \\
\hline
\end{tabular}

Standard errors in parentheses

$* * * p<0.01, * * p<0.05, * p<0.1$

panel data, "unobservable bilateral heterogeneity" must be controlled for. In this way, in our specific case, the inclusion of a variable with a different value for each pair which is constant over time would control for both "multilateral resistance" and "unobservable heterogeneity". We have also considered it interesting to add for each type of products and for all of Argentine exports, a second model in which the set of time-invariant country fixed effects has been replaced with non-overlapping period fixed effects (for every ten years). In addition, constituting an exercise to test robustness, these decadal interactions allow for variation in the unobservable heterogeneity throughout the period.

Finally, Santos Silva and Tenreyro (2006, 2010) explain the existence of serious econometric problems, such as heteroscedasticity and a very high number of zero values in the dependent variable. In our case particularly, the existence of these values is common when in certain years there is no trade of some products with some of the partners, especially in the models that take into account each group of products. If an OLS estimate were conducted, it may be biased. Consequently, we have used a nonlinear Poisson estimator to estimate the gravity equation which takes into account the presence of the zeros. This is known as the Poisson pseudo maximum likelihood (PPML) estimator.

\section{General results}

Our first model is a basic gravity equation which, in addition to the GDPs of Argentina and its trade partners, contemplates the transport costs and the tariff protection of the partners. The results reveal how both the GDP of the exporter (Argentina) and 
that of the importers are significant with a positive sign to explain the strong growth of Argentine exports (Table 4).

In the first case, we can say that the increase in Argentina's GDP was important to explain the export growth. Therefore, we support the idea that supply is a relevant variable to explain this growth. The increase in goods, in terms of both variety and volume, was due to changes in the production structure, as pointed out in the first section. On the one hand, new lands were successfully incorporated into the productive system. In fact, even though some authors have indicated that the expansion of the frontier reached its peak in around 1908 (for example, Bunge 1928 or Di Tella and Zymelman 1967), others (such as Cortés Conde 1997) explain that the uses of the lands changed, increasing their productivity or that the productivity grew as a consequence of more technology being applied in the agricultural sector during the 1920s (Gerchunoff 2016).

On the other hand, labour and capital, traditionally scarce factors, were supplied from abroad. The influx of immigrants contributed to the development of activities that required more labour than cattle farming, such as agriculture. There was an immigration which became permanent and altered the rates of population growth, but there was also seasonal immigration (Cortés Conde 1979: 192-194; Míguez 2001).

The entrance of foreign capital, basically from European countries, facilitated the construction or modernisation of infrastructures and the improvement in the production structure. The capital was mostly invested in railroads, ports, financial systems, urban services and cold storage plants (Regalsky 1986: 8 and 51).

As the production structure changed, the agriculture surpassed cattle activities in terms of exports. In fact, according to our calculations, during the whole period (1875-1929) the former accounted for $49 \%$ of the total export value, while the latter represented $45.5 \%$. The coexistence of them both strengthened the volume exported because the goods offered in international markets were varied. Indeed, the annual growth rate of the quantum was $4.6 \%$ between 1880 and 1929 .

The changes in the production structure not only encouraged exports but also played an important role in expanding the domestic market since the internal offer was more diversified than before and the internal demand increased as a consequence of the population growth. In fact, the GDP rose several times between 1875 and 1929 (Cortés Conde and Harriague 1994: 17) and a recent research demonstrated that the export sector had contributed to the Argentine economy in several aspects beyond its participation in the GDP (Kuntz-Ficker and Rayes 2017).

However, obviously without a strong demand for the type of goods in which the country successively specialised, the export business would not have developed sufficiently. Therefore, the demand for food and raw materials, particularly from the most developed European countries, was essential (Aparicio et al. 2018). The European population grew at a very fast pace during the First Globalisation as a result of the demographic transition that was taking place. Furthermore, the increase in per capita income due to the industrialisation process and the growing specialisation in manufacturing in these countries boosted their demand for these types of primary goods and food (O'Rourke and Williamson 2000). 
Although the reduction in overseas shipping costs has the expected negative sign in both models, it is only significant in the second, showing that thanks to these lower costs, the European countries that were the main importers of food and agricultural products were able to obtain them at competitive prices (Estevadeordal et al. 2003; Jacks et al. 2008).

Finally, the tariff liberalisation process is significant in both models, but with opposite signs. We believe that the results of this variable in the models for each type of products can explain this contradiction, but we should not rule out that the variable tariffs cannot be a good estimate of the real protection faced by the products exported by Argentina.

\section{Results by types of products}

We believe that a more in-depth understanding of the determinants of Argentina's export success may be gained if we disaggregate the country's total foreign sales by type of product. This is one of our main contributions since the existing literature tends to study overall exports or to observe the trajectory of the main products individually. On the contrary, we have tried to group them by taking in account their nature (whether they were derived from agriculture, livestock activities or if they were processed).

To do this, we have classified them into three groups: livestock products, crop products and processed agrifood products. As previously mentioned, the share that each of these products had of total exports changed over time. From the independence of the Río de La Plata region until the 1880s, exports were almost exclusively composed of livestock products.

These constituted the best option when Spain's Empire in America came to an end and the trade networks were split. With the Independence process, Buenos Aires lost the silver that exported and which came from Alto Peru (Halperin Donghi 1982). The Pampean provinces specialised in cattle goods (Salvatore and Newland 2003). Initially, the choice was the native bovine cattle and the subsequent production of tallow (used, for instance, to make candles), bovine and ovine hides (used mainly in the saddlery and footwear industry) and jerked meat (sent especially as food for slaves) (Giberti 1956; Montoya 1956; Amaral 1998; Rosal and Schmit 1999; Brown 2002). By the 1840s, wool began to become more prominent. The low cost of the initial investments, the immigration of farmers with knowledge about sheep breeding (for example, Irish people), the import of pedigree animals and the international demand by the textile industries in European countries and the USA were some of the reasons why Argentina became one of the major competitors in the wool market during the second half of the nineteenth century (Sabato 1989: 33-35). In fact, the boom took place in the 1860 s.

It can be observed that the Rio de la Plata region offered the raw materials that were increasingly demanded by those countries that were immersed in an industrialisation process. The goods offered in international markets depended naturally on the production possibilities of the region, related to the abundance or scarcity of the factors of production (Platt 1980). 
Table 5 Results of the gravity equation for Argentine livestock exports, 1880-1929

\begin{tabular}{lll}
\hline Variables & $(1)$ & $(2)$ \\
\hline 1_GDPi & $-0.528^{* * *}$ & $-0.516^{* *}$ \\
& $(0.148)$ & $(0.235)$ \\
1_GDPj & $1.560^{* * *}$ & $1.685^{* * *}$ \\
& $(0.190)$ & $(0.310)$ \\
1_Freight & $-1.594^{* * *}$ & $-2.156^{* * *}$ \\
& $(0.169)$ & $(0.417)$ \\
1_Tariff & -0.017 & $-0.405^{* * *}$ \\
& $(0.130)$ & $(0.111)$ \\
Year fixed effects & Yes & Yes \\
Time-invariant importer fixed effects & Yes & No \\
Importer decade fixed effects & No & Yes \\
Constant & -0.529 & -1.246 \\
& $(1.421)$ & $(1.554)$ \\
Observations & 550 & 540 \\
$R$ squared & 0.741 & 0.893 \\
\hline
\end{tabular}

Standard errors in parentheses

$* * * p<0.01, * * p<0.05, * p<0.1$

From the last decade of the nineteenth century, the importance of crop products grew significantly. As we have already indicated, these goods accounted for more than half of the total export value from the beginning of the twentieth century. Of the products in the export basket, wheat, corn and linseed particularly stood out. The area sown with these three grains grew by more than 55 times between 1872 and 1916 (Barsky and Gelman 2001: 161). This was possible thanks to the internal migration and immigration, the improvements in trading systems and the technical advances in production and transport.

Finally, processed products appeared with growing intensity from the beginning of the twentieth century. Of these goods, the most significant were frozen and chilled beef, frozen mutton, wheat flour and quebracho extract. They are all cases of forward linkages since they appeared in the export basket as a consequence of the development of primary activities (Geller 1975). They have also been considered as proof of a certain level of industrialisation in Argentina (Villanueva 1972; Gallo 1987) since they can be regarded as cases of light industry.

Table 5, corresponding to the basic gravity models for livestock products, reveals that the growth of external demand (GDP of trade partners) was decisive for export growth. Therefore, as the expansion of the industrialisation process in some European countries or in the USA increased, the demand for raw materials oriented to industries such as textile, footwear, furniture, and saddlery also increased. So, Argentine took advantage of the international needs.

In the same way, the fall in transport costs also favoured the growth of exports. Of course, the international and internal improvement in transports influenced the expansion of supply. For example, the sheep hides produced in the Patagonian region from the end of the nineteenth century were able to penetrate international 
Table 6 Results of the gravity equation for Argentine crop exports, 1880-1929

\begin{tabular}{lll}
\hline Variables & $(1)$ & $(2)$ \\
\hline 1_GDPi & $2.262^{* * * *}$ & $2.027 * * *$ \\
& $(0.291)$ & $(0.522)$ \\
1_GDPj & $1.732 * * *$ & $2.954 * * *$ \\
& $(0.276)$ & $(0.554)$ \\
1_Freight & 0.000 & $-0.419 * * *$ \\
& $(0.123)$ & $(0.089)$ \\
1_Tariff & $-0.384 * * *$ & $-0.226 *$ \\
& $(0.083)$ & $(0.137)$ \\
Year fixed effects & Yes & Yes \\
Time-invariant importer fixed effects & Yes & No \\
Importer decade fixed effects & No & Yes \\
Constant & $-34.60 * * *$ & $-48.48^{* * *}$ \\
& $(3.903)$ & $(5.328)$ \\
Observations & 400 & 389 \\
$R$ squared & 0.870 & 0.906 \\
\hline
\end{tabular}

Standard errors in parentheses

$* * * p<0.01, * * p<0.05, * p<0.1$

markets due to the changes in transport (Bandieri 2011). Tariffs are only significant in the second model with a negative sign.

A highly interesting result is the negative sign and statistically significant effect of Argentina's GDP. This means that the increase in this country's GDP negatively affected the export of these types of products. This result is coherent with our previous knowledge regarding Argentina's economic development. As we have already pointed out, initially, it was based on the use of the prairies of the Pampa region for livestock grazing and exported the products derived from it, such as wool, hides, tallow or live animals. This type of activity required a large amount of land, which was the country's most abundant factor of production. There was a shortage of labour, and the capital investments were very low, primarily concentrated in forming the initial herds, as no significant land transformations were necessary. However, the subsequent expansion of the Argentine economy gave rise to a shift towards more intensive activities such as agricultural crops, principally wheat, corn or linseed. Logically, the growth of these activities represented competition for the land and other factors of production used for the livestock sector. From a long-term perspective, cattle activities grew less than agricultural activities (Cortés Conde and Harriague 1994: 18).

Table 6 shows the results for the crop products. In this case, in addition to external demand (GDP of trade partners) the growth of Argentina's economy (GDP of Argentina) is also significant to explain the increase in the exports of agricultural products. The colonisation of the new lands, the arrival of capital, the immigrants from abroad, the domestic population flows or the construction of infrastructures such as railways were key factors to enable the growth of these types of exports. If the railroads had not been developed, connecting the main ports (Buenos Aires, 
Table 7 Results of the gravity equation for Argentine processed agrifood exports, 1880-1929

\begin{tabular}{llll}
\hline Variables & $(1)$ & $(2)$ & $(3)$ \\
\hline 1_GDPi & $3.999^{* * *}$ & $3.665^{* * *}$ & $1.805^{*}$ \\
& $(0.411)$ & $(0.950)$ & $(1.062)$ \\
1_GDPj & $-2.034^{* * *}$ & $-1.785^{* *}$ & 0.126 \\
& $(0.474)$ & $(0.907)$ & $(0.973)$ \\
1_Freight & $1.024^{* * *}$ & $2.976^{* * *}$ & 0.805 \\
& $(0.225)$ & $(1.055)$ & $(1.070)$ \\
1_Tariff & $-0.420^{* * *}$ & $-0.302^{*}$ & -0.276 \\
& $(0.119)$ & $(0.156)$ & $(0.191)$ \\
& $(0.196)$ & $(0.300)$ & $(0.183)$ \\
WWI years included & Yes & Yes & No \\
Year fixed effects & Yes & Yes & Yes \\
Time-invariant importer fixed effects & Yes & No & No \\
Importer decade fixed effects & No & Yes & Yes \\
Constant & $-14.66^{* * *}$ & $-7.814^{*}$ & $-11.20^{* *}$ \\
& $(4.702)$ & $(4.350)$ & $(4.365)$ \\
Observations & 450 & 410 & 360 \\
$R$ squared & 0.984 & 0.988 & 0.991 \\
\hline
\end{tabular}

Standard errors in parentheses

$* * * p<0.01, * * p<0.05,{ }^{*} p<0.1$

Rosario or Bahia Blanca) with the hinterland, the "heavy" products would not have been able to compete efficiently with the prices of Eastern Europe (Cortés Conde 1974).

In the same way as in the other cases, the fall in transport costs favoured export growth, which is shown by the significance of the variable and its negative sign in the second model. In fact, the agricultural products could reach distant markets because of the changes in transport costs.

In this case, the tariffs are significant in both models with a negative sign. This means that the reduction in tariffs favoured export growth. More importantly, the protectionist turnaround at the end of the nineteenth century, as a result of the agricultural depression caused by the competition of overseas grains with those from Europe, negatively affected the possibilities for the growth of Argentine agricultural exports (O'Rourke 1997). We know that this protectionist turnaround particularly affected wheat tariffs, diminishing Argentina's possibilities to export to the countries that implemented this increase in tariffs such as Germany, France, Italy or Spain. However, those markets that were still open, such as Denmark or Great Britain, enabled the export of Argentine grains to continue growing. The prohibition by countries such as Great Britain of the import of live animals boosted the export of Argentine corn to feed the domestic herds and contributed to stimulating the meat-packing industry.

In the case of processed agricultural products, we should point out that the most important were frozen beef and mutton or chilled beef, although goods such as wheat 
flour or quebracho products were also significant. In this group, the decisive role of Argentina's economic growth constitutes a principal factor to explain the increase in exports, as shown by Argentina's GDP, which is significant and has a positive sign (Table 7). In the case of meat, the technological change explains the export growth. New technology used for chilling or freezing meat enabled a very rapid growth in the exports of these types of products. It required more capital-some meat-packing plants were established with foreign capital and other with local funding-and the improvement in the animals slaughtered, which was achieved thanks to the crossbreeding with British species. The process started with sheep because their bodies were easier to freeze and continued with cows (Sesto 2005). The ovine industry was moved from the Buenos Aires Province to the Patagonian region where the process of capital accumulation depended on bovine farming which was complementary to agriculture production (Sabato 1989).

Two other industries which were more modest than the meat-packing process but which also depended on the expansion of the production structure were wheat milling and the extraction of quebracho (useful for dying leather and hides) (Rayes 2013a and Martirén and Rayes 2016).

The GDP of trade partners and the transport costs are significant, but both have the opposite sign to that expected, since it is negative for external demand and positive for transport costs. These apparently surprising results can be explained by the particular dynamics of the exports of these products during the First World War, when they experienced a great increase, just when the GDP of the main trading partners of Argentina experienced a severe reduction and maritime freight rates increased sharply. Thus, between 1914 and 1918, frozen beef was the main export product of Argentina, accounting for a much higher proportion of sales in this country than in the preceding or following years. These products, particularly frozen beef, were in high demand during the First World War because they were used for the troops' rations (Rayes 2014b). Therefore, the inclusion of the years between 1914 and 1918 in the model generates results that are difficult to explain. Thus, in model 3 we can observe that when the years of the War are excluded, both the GDP of the importers and the maritime freights cease to be significant.

But the War not only affected exports of processed agricultural products. They had a distorting effect on Argentine exports, depending on their destination. To evaluate its impact, we have proposed an expanded gravity model in which we have included two additional dummy variables. The first takes the value of 1 for the European countries during the years of the First World War, and the second also takes the value of 1 during the same years but for the countries of the American continent. The objective is to attempt to capture the disruptions caused to trade with Europe due to the conflict and the possible incentives, given this exceptional situation, for trade with Latin American countries (Badía-Miró and Carreras-Marín 2012; Carreras-Marín et al. 2013) and the USA. These variables that measure the effects of the war are significant and have the expected signs (see Appendix 2 in the Supplementary material): negative for Europe and positive for the Americas. In other words, the military activity in Europe, submarine warfare and the blockade of the allies against the German and Austro-Hungarian empires seriously affected the Argentine exports sent to this continent. This result is highly consistent with previous studies 
that have addressed this subject (Albert 1988: 56-61; Offer 1989; Aparicio et al. 2009: 69-70; Pinilla and Aparicio 2015: 233-234). On the other hand, the war favoured the increase in exports to the American continent, particularly to the USA, which acted as an intermediary between the Allies. We believe that the main explanation for this is the increase in regional trade between the Latin American countries (Badía-Miró et al. 2018). The only exception to this general behaviour is the case of exports of processed agrifood products that show a positive sign and is significant when their destination is Europe. This confirms the strategic role of exports of frozen beef for rations for soldiers.

\section{Concluding remarks}

As the Argentine case has been widely studied, we must define the main contributions that we wish to make. First, new empirical evidence is presented and analysed. Second, an econometric model to analyse Argentine exports between 1880 and 1929 is tested, which, as far as we know, has never been done for this topic. Third, we have not only drawn conclusions about the export experience in general, but we have also done so for the different groups of products. In fact, the paper confirms our main hypothesis. We defend that Argentina's export-led growth must be explained from both the supply and demand sides. We also support the idea that Argentina had a successful agro-export sector because it offered a diverse basket of products to the different European and American countries that consumed them. In other words, grains and meat, which became stronger after the final decade of the nineteenth century, joined the livestock products that Argentina traditionally exported. Therefore, Argentina did not depend on one market or on one product, which, according to the previous literature, was the case of other Latin American countries. This paper suggests that only an observation from both the demand and supply sides and from a dynamic perspective can explain the sustained export growth between the 1880s and the Great Depression. We have also found that the reduction in transport costs boosted exports. It is important to clarify that we have placed emphasis on transport cost given that we have quantified and included them in the econometric model. Nevertheless, we believe that what favoured the Argentine integration into the international markets was not only the decline in transport costs but also the dramatic decrease in trade costs since the insurance rates and handling costs in ports fell even more significantly than maritime freight rates, which were already low by the $1850 \mathrm{~s}$. Tariffs also had a significant effect on most of the exports of Argentina. The process of trade liberalisation that took place during the first wave of globalisation was therefore key to explaining the rapid increase in Argentine exports. According to our model, the First World War greatly inhibited exports to Europe but intensified those sold to the American continent, with the exception of frozen beef whose exports to Europe grew substantially during the war. To sum up, we can conclude that Argentina took advantage of a multilateral and open economic system. Within this context, the country generally found a demand for its supply, which constitutes the key to explaining the magnitude and speed of Argentina's export growth. 
Acknowledgements This study has received financial support from Spain's Ministry of Economy and Competitiveness, project ECO2015-65582-P, the Government of Aragon, through the Research Group S55_17R and from the National Foundation for Scientific and Technical Research of the Argentine Ministry of Science, Technology and Innovation (PICT 2016-1912). The authors wish to thank Leticia ArroyoAbad, María Isabel Ayuda, Marc Badia-Miro, Anna Carreras, Roberto Cortés Conde, Hugo Ferrer, Elena Martínez, Chriss Meissner, Eduardo Míguez, Pilar Nogués-Marco, Federico d'Onofrio, Marcela Sabaté, Isabel Sanz, Steve Stein, Raúl Serrano, Henry Willebald and participants at the Economic History Seminar of the University of Zaragoza, the Vienna Frontier Research in Economic and Social History Meeting, Agricliometrics III (University of Cambridge), the Ridge Forum May 2017 (Montevideo), the Pre-session and session on Agricultural Efficiency in the Great Specialization at Vienna University of Economics and Business and at the Boston World Economic History Congress, the Natural Resources Management workshop held at the University of Barcelona, for their help and advice. We also thank the editor and the anonymous referees who provided insightful comments prior to publication. The usual disclaimers apply.

\section{References}

Albert B (1988) South America and the first world war. The impact of the war on Brazil, Argentina, Peru and Chile. Cambridge University Press, Cambridge

Alvarez J, Bertola L, Porcile G (2007) Primos ricos y empobrecidos. Crecimiento, distribución del ingreso e instituciones en Australia-Nueva Zelanda vs Argentina-Uruguay. Fin de siglo, Montevideo

Amaral S (1998) The rise of capitalism on the Pampas: the estancias of Buenos Aires, 1785-1870. Cambridge University Press, Cambridge

Anderson JE (1979) A theoretical foundation for the gravity equation. Am Econ Rev 69:106-116

Anderson JE, van Wincoop E (2003) Gravity with gravitas: a solution to the border puzzle. Am Econ Rev 93:170-192

Aparicio G, Pinilla V, Serrano R (2009) Europe and the international agricultural and food trade, 18702000. In: Lains P, Pinilla V (eds) Agriculture and economic development in Europe since 1870. Routledge, London, pp 52-75

Aparicio G, González AL, Pinilla V, Serrano R (2018) The world periphery in global agricultural and food trade, 1900-2000. In: Pinilla V, Willebald H (eds) Agricultural development in the world periphery: a global economic history approach. Palgrave, London, pp 63-88

Badía-Miró M, Carreras-Marín A (2012) Latin America and its main trade partners, 1860-1930: did the first world war affect geographical patterns. In: Yáñez C, Carreras A (eds) The economies of Latin America: new cliometric data. Pickering and Chatto, London, pp 59-62

Badía-Miró M, Carreras-Marín A, Meissner C (2018) Geography, policy, or productivity? Regional trade in five South American countries, 1910-50. Econ Hist Rev 71:236-266

Bandieri S (2011) Historia de la Patagonia. Sudamericana, Buenos Aires

Barsky O, Gelman J (2001) Historia del agro en la Argentina: desde la conquista hasta el siglo XX. Grijalbo-Mondadori, Buenos Aires

Bergstrand JH (1985) The gravity equation in international trade: some microeconomic foundations and empirical evidence. Rev Econ Stat 67:474-481

Bergstrand JH (1989) The generalised gravity equation, monopolistic, and the factor-proportions theory in international trade. Rev Econ Stat 71:143-153

Bértola L, Ocampo JA (2013) El desarrollo económico de América Latina desde la Independencia. Fondo de Cultura Económica, Mexico

Brown JC (2002) Historia socioeconómica de la Argentina: 1776-1860. Instituto Torcuato Di Tella, Buenos Aires

Bulmer-Thomas V (1994) La historia económica de América Latina desde la independencia. Fondo de Cultura Económica, Mexico

Bunge A (1928) La economía argentina, vol 2. Agencia General de Librerías y Publicaciones, Buenos Aires

Cardenas E, Ocampo JA, Thorp R (2003) Introducción. In: Ocampo JA, Thorp R (eds) Cárdenas E. La era de las exportaciones latinoamericanas. De fines del siglo XIX a principios del XX. Fondo de Cultura Económica, Mexico 
Carreras-Marín A, Badia-Miró M, Peres Cajías J (2013) Intraregional trade in South America, 19121950: the cases of Argentina, Bolivia, Brazil, Chile and Peru. Econ Hist Dev Reg 28:1-26

Clemens MA, Williamson JG (2004) Why did the tariff-growth correlation change after 1950? J Econ Growth 9:5-46

Cortés Conde R (1974) Hispanoamérica: la Apertura del Comercio Mundial, 1850-1930. Editorial Paidós, Buenos Aires

Cortés Conde R (1979) El progreso argentino 1880-1914. Sudamericana, Buenos Aires

Cortés Conde R, Hunt S (eds) (1985) The export economy of Argentina, 1880-1920. The Latin American economies: growth and the export sector 1880-1930. Holmes, Nueva York, pp 319-391

Cortés Conde R (1997) La economía argentina en el largo plazo (Siglos XIX y XX). Sudamericana, Buenos Aires

Cortés Conde R (2003) Las vicisitudes de una economía exportadora. In: Ocampo JA, Thorp R (eds) La era de las exportaciones latinoamericanas. De fines del siglo XIX a principios del XX. Fondo de Cultura Económica, Mexico, pp 360-417

Cortés Conde R, Harriague MM (1994) Estimaciones del Producto Bruto Interno de Argentina 18751935. Universidad de San Andrés, Victoria

Cortés Conde R, Halperin Donghi T, Gorostegui de Torres H (1965) Evolución del Comercio Exterior Argentino I. Exportaciones. Instituto Torcuato Di Tella, Buenos Aires

Deardorff A (1984) Testing trade theories and predicting trade flows. In: Jones R, Kenen P (eds) Handbook of international economics. North Holland, Amsterdam, pp 467-517

Denoon D (1983) Settler capitalism: the dynamics of dependent development in the southern hemisphere. Clarendon Press, Oxford

Di Tella G, Zymelman M (1967) Las etapas del desarrollo económico argentino. Editorial Universitaria de Buenos Aires, Buenos Aires

Díaz Alejandro CF (2002) Ensayos sobre la historia económica argentina. Amorrortu, Buenos Aires

Duncan WT (1984) Australia and Argentina: on parallel paths. Melbourne University Press, Carlton

Estevadeordal A, Frantz B, Taylor AM (2003) The rise and fall of world trade, 1870-1939. Q J Econ 118:359-407

Evenett SJ, Keller W (2002) On theories explaining the success of the gravity equation. J Polit Econ 110:281-316

Fajgelbaum P, Redding SJ (2014) External integration, structural transformation and economic development: evidence from Argentina, 1870-1914. NBER Working Paper Series 20217: 1-56

Federico G, Tena-Junguito A (2016) World trade, 1800-1938: a new data-set. Eur Hist Econ Soc 93:1-351

Feenstra RC, Markusen JA, Rose AK (1998) Using the gravity equation to differentiate among alternatives theories of trade. Can J Econ 34:430-447

Ferrer A (2008) La economía argentina. Desde sus orígenes hasta principios del siglo XXI. Fondo de Cultura Económica, Mexico

Ferreres O (2010) Dos siglos de economía argentina (1810-2010). Historia argentina en cifras. El Ateneo, Buenos Aires

Findlay R, Lundahl M (2017) The economics of the frontier. Conquest and settlement. Palgrave Macmillan, London

Fodor J, O’Connell A (1973) La Argentina y la Economía Atlántica en la Primera Mitad del Siglo XX. Desarrollo Económico 49:3-65

Fogarty J (1985) Staples, super-staples and the limits of staple theory: the experiences of Argentina, Australia and Canada compared. In: Platt DCM, Di Tella G (eds) Argentina, Australia and Canada. Studies in comparative development 1870-1965. Macmillan, London, pp 19-35

Ford A (1966) El patrón-oro: 1880-1914. Inglaterra y Argentina. Editorial del Instituto, Buenos Aires

Francis J (2017) Globalisation, the terms of trade, and Argentina's expansion in the long nineteenth century. J Latin Am Stud 49:709-738

Gallo E (1987) La expansión agraria y el desarrollo industrial en Argentina (1880-1930). Anuario IEHS 13:13-25

Geller L (1975) El crecimiento industrial argentino hasta 1914 y la teoría del bien primario exportable. In: Giménez Zapiola M (ed) El régimen oligárquico: materiales para el estudio de la realidad argentina (hasta 1930). Amorrortu, Buenos Aires, pp 152-200

Gerchunoff P (2016) En busca del eslabón perdido. La economía política de los gobiernos radicales, 1916-1930. Edhasa, Buenos Aires 
Gerchunoff P, Aguirre H (2006) La economía argentina entre la Gran Guerra y la Gran Depresión. Estudios y Perspectivas de la CEPAL 32:1-87

Gerchunoff P, Llach L (2007) El ciclo de la ilusión y el desencanto. Un siglo de políticas económicas argentinas. Emecé, Buenos Aires

Gerchunoff P, Llach L (2008) Antes y después del "corto siglo XX”. Dos globalizaciones latioamericanas (1850-1914 y 1980-2000s). XXI Jornadas de la Asociación Argentina de Historia Económica, Caseros

Giberti H (1956) Historia económica de la ganadería argentina. Solar, Buenos Aires

Gravil R (1985) The Anglo-Argentine connections, 1900-1939. Westview Press, Boulder

Halperin Donghi T (1982) Guerra y finanzas en los orígenes del Estado Argentino (1791-1850). Editorial de Belgrano, Buenos Aires

Helpman E (1987) Imperfect competition and international trade: evidence from fourteen industrial countries. J Jpn Int Econ 1:62-81

Helpman E, Krugman P (1985) Market structure and foreign trade; increasing returns, imperfect competition, and the international economy. MIT press, Cambridge

Hummels D, Levinsohn J (1995) Monopolistic competition and international trade: reconsidering the evidence. Q J Econ 110:799-836

Jacks DJ (2006) What drove 19th century commodity market integration? Explor Econ Hist 43:383-412

Jacks DJ, Meissner CM, Novy D (2008) Trade costs, 1870-2000. Am Econ Rev 98:529-534

Jacks DJ, Meissner CM, Novy D (2011) Trade booms, trade busts, and trade costs. J Int Econ 83:185-201

Kuntz-Ficker S (2017) Latin America's first export era: a preliminary balance (toward a new synthesis). In: Kuntz-Ficker S (ed) The first export era revisited. Reassesing its contribution to Latin American economies. Palgrave Macmillan, London, pp 313-336

Kuntz-Ficker S, Rayes A (2017) The contribution of argentine exports to the economy, 1875-1929. In: Kuntz-Ficker S (ed) The first export era revisited. Reassesing its contribution to latin American economies. Palgrave Macmillan, London, pp 37-72

League of Nations (1942) The network of world trade. A Companion Volume to "Europe's Trade". League of Nations Geneva

Lloyd C, Metzer J, Sutch R (eds) (2013) Settler economies in world history. Brill, Leiden-Boston

Maddison project (2013) http://www.ggdc.net/maddison/maddison-project/home.htm, 2013 version. Accessed 2 Oct 2015

Martirén JL, Rayes A (2016) La Industria Argentina de harina de trigo en el cambio de siglo. Límites y Alcances, 1880-1914. H-Industri@: revista de historia de la industria, los servicios y las empresas en. América Latina 18:1-27

Míguez E (2001) El mercado de trabajo y la estrategia de los migrantes en el flujo trasatlántico de mano de obra hacia la Argentina. Un panorama. Estudios Migratorios Latinoamericanos 49:443-462

Míguez E (2008) Historia económica de la Argentina: De la conquista a la crisis de 1930. Editorial Sudamericana, Buenos Aires

Míguez E, Rayes A (2014) La naturaleza de la dependencia, la dependencia de la naturaleza. Las exportaciones argentinas 1890-1938 en perspectiva comparada. Desarrollo Económico 211:313-344

Montoya A (1956) Historia de los saladeros argentinos. Raigal, Buenos Aires

O'Connell A (1984) La Argentina en la Depresión. Los problemas de una economía abierta. Desarrollo Económico 92:479-514

Offer A (1989) The first world war: an agrarian interpretation. Clarendon Press, Oxford

O'Rourke KH (1997) The european grain invasion, 1870-1913. J Econ Hist 57:775-801

O'Rourke KH, Williamson J (2000) Globalization and history: the evolution of a nineteenth-century Atlantic economy. US MIT, Cambridge

Peterson H (1964) Argentina and the United States 1810-1960. State University of New York, New York

Pinilla V, Aparicio G (2015) Navigating in troubled waters: south American exports of food and agricultural products, 1900-1950. Revista de Historia Económica J Iber Latin Am Econ Hist 33:223-255

Pinilla V, Ayuda MI (2010) Taking advantage of globalization? Spain and the building of the International market in Mediterranean horticultural products, 1850-1935. Eur Rev Econ Hist 14:239-274

Platt DCM (1972) Latin America and british trade 1806-1914. Adam and Charles Black, London

Platt DCM (1980) Objeciones de un historiador a la teoría de la dependencia en América Latina en el siglo XIX. Desarrollo Económico 76:435-451

Pomfret R (1981) The staple theory as an approach to Canadian and Australian economic development. Aust Econ Hist Rev 21:133-146 
Rayes A (2013a) Más allá de la ganadería y la agricultura. Las exportaciones argentinas de quebracho, 1890-1913. Folia Histórica del Nordeste 21:141-154

Rayes A (2013b) Bestias negras de la estadística. Las exportaciones argentinas "a órdenes", 1895-1913. Estadística e Sociedade 3:6-20

Rayes A (2014a) Sobreviviendo en el cambio. Las exportaciones argentinas de lanas y cueros en tiempos de cereales y frigoríficos, 1890-1913. Revista Quinto Sol 18:1-22

Rayes A (2014b) Los destinos de las exportaciones y la neutralidad argentina durante la Primera Guerra Mundial. Política y Cultura 42:31-52

Rayes A (2015) La estadística de las exportaciones argentinas, 1875-1913. Nuevas evidencias e interpretaciones. Investigaciones de Historia Económica 11:31-42

Regalsky A (1986) Las inversiones Extranjeras en la Argentina. Centro Editor de América Latina, Buenos Aires

Rocchi F (2011) Argentina en el mundo. In: Míguez E (ed) Argentina. La apertura al mundo, 1880-1930. Santillana-Fundación Mapfre, Madrid, pp 95-149

Rosal M, Schmit R (1999) Del reformismo borbónico al librecomercio: las exportaciones pecuarias del Río de La Plata (1768-1854). Boletín del Instituto de Historia Argentina y Americana "Dr Emilio Ravignani” 20:69-109

Rubio M (2011) But they buy (despite duties!) Latin America custom duties and trade during de pre-1914 Belle-Epoque. X Congreso Internacional de la AEHE, Sevilla

Sabato H (1989) Capitalismo y ganadería en Buenos Aires: la fiebre del lanar 1865-1890. Sudamericana, Buenos Aires

Salvatore R, Newland C (2003) Between independence and the golden age: the early argentine economy. In: Della Paolera G, Taylor A (eds) A new economic history of argentina. Cambridge University Press, Cambridge, pp 19-45

Santos Silva JMC, Tenreyro S (2006) The log of gravity. Rev Econ Stat 88:641-658

Schedvin CB (1990) Staples and regions of pax britannica. Econ Hist Rev 43:533-559

Sesto C (2005) Historia del capitalismo agrario argentino. La vanguardia ganadera bonaerense, 18561900. Universidad de Belgrano-Siglo XXI, Buenos Aires

Smithies A (1966) Crecimiento económico: comparaciones internacionales. Argentina y Australia. Fundación de Investigaciones Económicas Latinoamericanas, Buenos Aires

Tena-Junguito A, Willebald H (2013) On the accuracy of export growth in Argentina, 1870-1913. Econ Hist Dev Reg 28:28-68

Vázquez Presedo V (1971) Estadísticas históricas argentinas (comparadas). Primera parte, 1875-1914. Ediciones Macchi, Buenos Aires

Vázquez Presedo V (1979) El Caso Argentino: Migración de Factores, Comercio Exterior y Desarrollo 1875-1914. Editorial Universitaria de Buenos Aires, Buenos Aires

Villanueva J (1972) El origen de la industrialización argentina. Desarrollo Económico 47:451-476

Vitelli G (2012) Los dos siglos de la Argentina. Historia económica comparada. Centro Cultural de la Cooperación Floreal Gorini-Universidad Nacional de Quilmes, Buenos Aires

Watkins M (1963) A staple theory of economic growth. Can J Econ Political Sci 29:83-95

Weinmann R (1994) Argentina en la Primera Guerra Mundial. Neutralidad, transición política y continuismo económico. Biblos, Buenos Aires

Winograd C, Véganzonès MA (1997) Argentina in the 20th Century: an accounted of long-awaited growth. OECD, Paris

\section{Official publications}

Argentine Official statistics of foreign trade, Buenos Aires, various editions (1870-1930) 